\title{
Examination of aerial diatom flushing across watersheds in Luxembourg, Oregon and Slovakia for tracing episodic hydrological connectivity
}

\author{
Laurent Pfister $^{1 *}$, Carlos E. Wetzel ${ }^{1}$, Núria Martínez-Carreras ${ }^{1}$, Jean François Iffly ${ }^{1}$, Julian Klaus ${ }^{1}$, \\ Ladislav Holko ${ }^{2}$, Jeffrey J. McDonnel1 ${ }^{3,4}$ \\ ${ }^{1}$ Luxembourg Institute of Science and Technology, Department Environmental Research and Innovation, 5 avenue des Hauts-Fourneaux, \\ L-4362 Esch/Alzette, Luxembourg. \\ ${ }^{2}$ Institute of Hydrology, Slovak Academy of Sciences, Liptovský Mikuláš, Slovak Republic. \\ ${ }^{3}$ University of Saskatchewan, Global Institute for Water Security, 11 Innovation Boulevard, SK S7N 3H5 Saskatoon, Canada. \\ ${ }^{4}$ School of Geosciences, University of Aberdeen, Meston Building, Old Aberdeen, AB24 3UE, Aberdeen, Scotland. \\ * Corresponding author. E-mail: laurent.pfister@list.lu
}

\begin{abstract}
Hydrological processes research remains a field that is severely measurement limited. While conventional tracers (geochemicals, isotopes) have brought extremely valuable insights into water source and flowpaths, they nonetheless have limitations that clearly constrain their range of application. Integrating hydrology and ecology in catchment science has been repeatedly advocated as offering potential for interdisciplinary studies that are eventually to provide a holistic view of catchment functioning. In this context, aerial diatoms have been shown to have the potential for detecting of the onset/cessation of rapid water flowpaths within the hillslope-riparian zone-stream continuum. However, many open questions prevail as to aerial diatom reservoir size, depletion and recovery, as well as to their mobilisation and transport processes. Moreover, aerial diatoms remain poorly known compared to freshwater species and new species are still being discovered. Here, we ask whether aerial diatom flushing can be observed in three catchments with contrasting physiographic characteristics in Luxembourg, Oregon (USA) and Slovakia. This is a prerequisite for qualifying aerial diatoms as a robust indicator of the onset/cessation of rapid water flowpaths across a wider range of physiographical contexts. One species in particular, (Hantzschia amphioxys (Ehr.) Grunow), was found to be common to the three investigated catchments. Aerial diatom species were flushed, in different relative proportions, to the river network during rainfall-runoff events in all three catchments. Our take-away message from this preliminary examination is that aerial diatoms appear to have a potential for tracing episodic hydrological connectivity through a wider range of physiographic contexts and therefore serve as a complementary tool to conventional hydrological tracers.
\end{abstract}

Keywords: Aerial diatoms; Hillslope-riparian zone-stream continuum; Hydrological connectivity.

\section{INTRODUCTION}

Over the past decades, conventional tracers used in experimental hydrology have considerably improved our understanding of time- and geographic sources of streamwater (Hooper et al., 1990; Martinec, 1975; Sklash and Farvolden, 1979). However, these approaches also have well-known limitations (e.g. Burns, 2002; McGuire and McDonnell, 2006) and hydrological processes research remains a field that is severely measurement limited.

In this context, the interface between hydrological and ecological sciences has been recognized as a major research frontier. How hydrological systems control ecological systems and vice-versa is a grand challenge in the emerging field of ecohydrology (Kundzewicz, 2012). This question eventually bears considerable potential for bringing new momentum to our understanding of questions related to water sources and flowpaths (Hannah et al., 2007; Tetzlaff et al., 2007).

In order to overcome limitations inherent to conventional geochemical tracers (e.g. scale constraints, incomplete mixing), recent work by Pfister et al. (2009) has explored the potential for aerial diatoms (i.e. species mainly occurring on wet and moist or temporarily dry places or species occurring nearly exclusively outside water bodies) to serve as a biological tracer of hydrological processes. Diatoms are unicellular eukaryotic algae and they are known to be ubiquitous (Round et al., 1990). Their habitats cover both the aerial and aquatic environment. Aerial diatoms are sensitive to a large variety of environmental variables, such as light, moisture conditions, temperature, water velocity, salinity, $\mathrm{pH}$, oxygen, inorganic nutrients (carbon, phosphorous, nitrogen, silica), organic carbon and organic nitrogen (Van Dam et al., 1994). Diatoms have been used frequently in geological, archaeological and water quality research (Smol and Stoermer, 2010; Van Dam et al., 1994).

Recent work by Pfister et al. (2009) has shown the potential for aerial diatoms - being flushed to the stream during rainfallrunoff events - to reveal rapid flowpaths connectivity within the hillslope-riparian zone-stream continuum of a small schistous catchment in Luxembourg. In a similar context, diatoms have been used recently as an indicator of tile drainage flow in a lowland catchment in Germany (Wu et al., 2014).

Many questions still exist regarding aerial diatoms and their use as tracers for hydrological processes across different environments (i.e. physiographic settings). Since diatom research has focused mainly on freshwater species (e.g. Bottin et al., 2014; Hlúbiková et al., 2014), new aerial species of diatoms are regularly discovered (Falasco et al., 2015; Furey et al., 2011, 2012; Johansen, 2010; Veselá and Johansen, 2009; Wetzel et al., 2014; Zimmermann et al., 2014). Open questions relate to aerial diatom reservoir size, depletion and recovery rates in case of precipitation events (Coles et al., 2015). Exploratory work in the schistous Weierbach catchment (Luxembourg) has shown that riparian zones hold the largest aerial diatom reservoirs, in comparison to hillslopes (MartínezCarreras et al., 2015). Mobilisation and (surface or sub-surface) 
transport processes of aerial diatoms during rainfall-runoff events are currently also investigated (Tauro et al., 2015).

Here, we explore the potential for aerial diatoms to trace rapid water flowpaths in three different environments in Oregon, Slovakia and Luxembourg. Climate conditions are contrasting between the Oregon site (with Mediterranean climate, with wet, mild winters and exceptionally dry, cool summers), the Luxembourg site (with a temperate oceanic climate, characterised by mild and wet winters) and the Slovak site (mountain continental climate with warm summers, cold winters and significant influence of seasonal snow cover). We hypothesize that aerial diatoms are present in all three settings and that they can serve for identifying the onset/cessation of rapid water flowpaths connectivity. More specifically, we ask whether aerial diatom flushing to the stream can be observed in all three catchments. This is a prerequisite for qualifying aerial diatoms as a robust indicator of the onset/cessation of rapid water flowpaths - and their connectedness to the stream - across a wider range of physiographical contexts. Our approach consists in: (1) collecting drift diatoms before, during and after rainfall-runoff events in all three catchments, (2) determining the presence/absence of aerial species in all samples, and (3) relate hydrological descriptors (e.g. precipitation intensity, stormflow coefficients) to aerial diatom contributions to the storm hydrographs.

\section{STUDY AREAS}

The Attert River basin is located in the northwest of Luxembourg (Fig. 1). It covers an area of $249 \mathrm{~km}^{2}$ and lies on the contact zone of the schistose Ardennes massif and the sedimentary Paris Basin. The Ardennes massif is a high subhorizontal plateau with average altitudes ranging between 450 and $500 \mathrm{~m}$. It covers the northern part of the catchment and is made of Devonian schists, phyllites and quartzite. The plateau surfaces are mainly under pasture, whereas the steep valley slopes are forested with coniferous and deciduous trees. The sedimentary Paris Basin covers the middle and southern part of the basin and has its topography characterized by gently sloping lowlands. Keuper sandy marls and Jurassic sandstones dominate the lithology. Landuse is characterised by patches of forest and lands dedicated mostly to grassland and agriculture. The hydrological regime of the Attert River is pluvial oceanic (Salvia-Castellví et al., 2005), with low flows from July to September (largely influenced by evapotranspiration losses), and high flows from December to February (dormant season). The mean annual precipitation for the study area (1954-1996) is estimated $853 \mathrm{~mm}$ (Pfister et al., 2000).

The Oak creek catchment is located in Benton County, OR, USA (Fig. 1). For this study, we have focused at a small sub-catch- a) Attert catchment at Useldange (LUXEMBOURG)

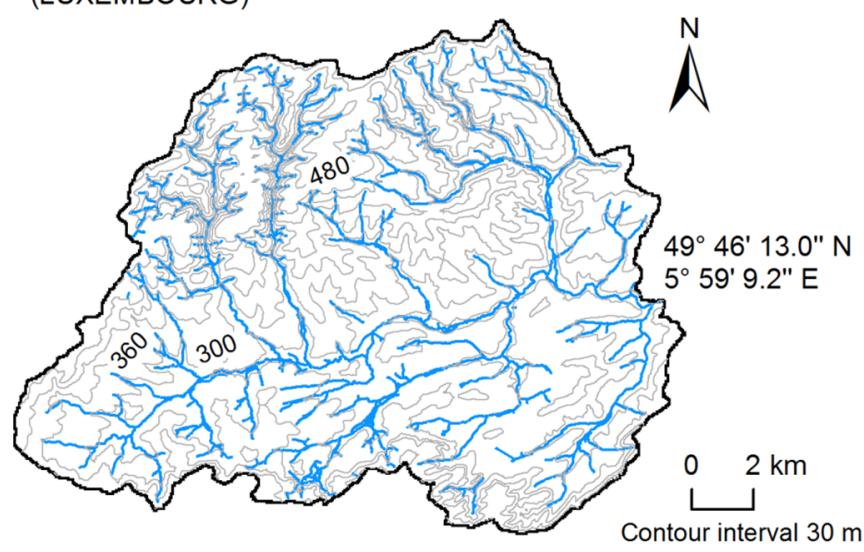

b) Oak creek catchment (USA)

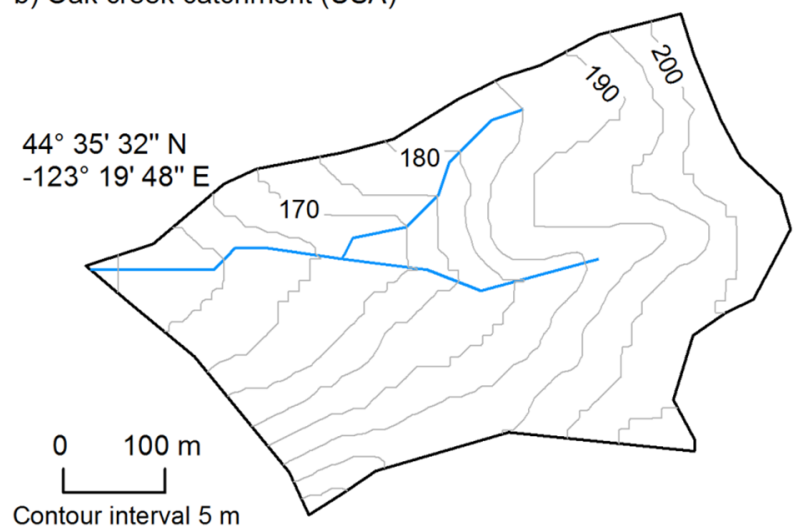

c) Jalovecký creek catchment (SLOVAKIA)



$49^{\circ} 9^{\prime} 46.3^{\prime \prime} \mathrm{N}$ $19^{\circ} 38^{\prime} 44.4^{\prime \prime} \mathrm{E}$

Fig. 1. Maps of a) the Attert River basin $-249 \mathrm{~km}^{2}$ (Luxembourg), b) the Oak creek catchment $-0.17 \mathrm{~km}^{2}$ (Oregon, USA) and c) the Jalovecký creek catchment $-22.2 \mathrm{~km}^{2}$ (Slovakia). All catchment areas are related to the outlets. 
ment of $0.17 \mathrm{~km}^{2}$, with altitudes ranging from $155 \mathrm{~m}$ to $195 \mathrm{~m}$ a.s.l. The geology consists of Tertiary Siletz River Volcanics. Landuse is dominated by pasture, with some farm buildings. The catchment has a large riparian zone that extends along the main stretches of the creek. The climate is Mediterranean and annual precipitation is $1109 \mathrm{~mm}$ (near Corvallis, Oregon 1971-2000). For our investigations, we have temporarily installed a recording precipitation gauge and a flow logger (operating at 15 minute time-step in March 2012).

The Jalovecký creek is located in the highest part of the Carpathian Mountains, northern Slovakia (Fig. 1). The catchment covers an area of $22.2 \mathrm{~km}^{2}$. Topography is characterised by a mean slope of $30^{\circ}$ and elevation ranges from 800 to $2178 \mathrm{~m}$ a.s.1. (mean elevation of $1500 \mathrm{~m}$ a.s.1.). Crystalline rocks (gneiss, granodiorite) covered with Quaternary moraines and loose slope sediments dominate. Land use is dominated by coniferous forest (mainly spruce), dwarf pine and alpine meadows. Mean annual precipitation in the catchment is $1562 \mathrm{~mm}$ and mean annual discharge is $1015 \mathrm{~mm}$ (data 19892005). Mean annual air temperature at catchment mean elevation is about $3^{\circ} \mathrm{C}$. Precipitation is highest in summer (July) and minimum in winter (January). Maximum seasonal discharge occurs in May as a result of the combined effects of snowmelt and spring precipitation. Minimum discharge occurs at the end of winter (February), when precipitation fallen over the last few months (typically since December) has accumulated as seasonal snow cover.

\section{METHODOLOGY}

We monitored precipitation and discharge in all three study catchments ( 15 to 60 minute time steps). Automatic samplers were installed for drift diatom collection during rainfall-runoff events on the following dates:

- Attert River (Luxembourg): 3-5 December $2011(\mathrm{n}=16)$

- Oak creek (Oregon): 10-14 March 2012 ( $\mathrm{n}=27$ )

- Jalovecký creek (Slovakia): 13-15 September $2012(\mathrm{n}=8)$

For all monitored events, we determined the total precipitation and discharge volumes, as well as the corresponding stormflow coefficients (determined through a linear baseflowstormflow hydrograph separation).

Water samples taken with automatic samplers during the rainfall-runoff events were centrifuged ( $1250 \mathrm{rpm}, 8$ minutes) to concentrate the organic material. Subsamples were cleaned (digested) using concentrated hydrogen peroxide $\left(\mathrm{H}_{2} \mathrm{O}_{2}\right)$ and heated for 24-48 h using a sand bath. Preparations were then allowed to cool and settle for $24 \mathrm{~h}$, and 80 to $90 \%$ of the supernatant was eliminated by vacuum aspiration. A volume of $1 \mathrm{ml}$ of $\mathrm{HCl}(37 \%)$ was then added and the mixture was allowed to stand for $2 \mathrm{~h}$, followed by three repetitions of rinsing and de- cantation using deionized water, following the procedure CEN 13946 (European Committee for Standardization, 2003). The cleaned suspension was mounted in a permanent slide using Naphrax as mounting medium. For the semi-quantitative analyses all individuals found in random transects under light microscopy across each permanent slide $(\mathrm{n}=55)$ were identified and counted, up to a minimum of 400 valves, using a Leica DMRX microscope at 1000x magnification. The laboratory procedures follow the guidance of the European standard CEN 14407 (European Committee for Standardization, 2014) for identification, enumeration and interpretation of diatom samples from running water.

Identification of diatom assemblages was based mainly on common freshwater floristic works such as Werum and LangeBertalot (2004) and Hofmann et al. (2011). Additional information concerning aerial diatom species were found in Petersen (1915, 1928, 1935), Hustedt (1942), Lund (1945), Brendemühl (1949), Simonsen (1987) and Ettl and Gärtner (2014).

Aerial diatom communities, defined as those communities living exposed to the air outside of lentic and lotic environments (Johansen, 2010), were considered as the categories 4 and 5 of the Van Dam et al. (1994) classification. Van Dam et al. (1994) is the only formal classification of the occurrence of freshwater diatoms in relation to moisture and is based on the knowledge of over half a century of diatom research by many authors; we used the associated hydrological units assigned by Pfister et al. (2009) to the five diatom occurrence classes defined by Van Dam et al. (1994). Specifically, we mainly expressed results as percentage (relative abundance) of aerophytic and aerial diatom valves, i.e. categories 4 and 5 . The calculations were made using the OMNIDIA software (Lecointe et al., 1993), version 5.3 (updated database 2014).

\section{RESULTS}

\section{Observed rainfall-runoff events}

Results for the three monitored rainfall-runoff events and associated diatom drift assemblages for the three catchments located in Luxembourg, Oregon and Slovakia are shown in Table 1. While precipitation totals were rather similar and moderate in the Luxembourgish and Slovak catchments (ranging from 11.3 to $15.6 \mathrm{~mm}$ ), the rainfall event recorded in Oregon was quite large $(40.1 \mathrm{~mm})$. Maximum precipitation intensity was also significantly higher in the Oak creek $\left(6.6 \mathrm{~mm} \cdot \mathrm{h}^{-1}\right)$, compared to that measured in the two other catchments $\left(0.9\right.$ to $\left.2.4 \mathrm{~mm} \cdot \mathrm{h}^{-1}\right)$. Runoff response in the catchments was assessed against the antecedent wetness conditions and precipitation characteristics. The precipitation event triggered only marginal runoff response in the Jalovecký creek, with a stormflow coefficient of approximately $0.3 \%$.

Table 1. Precipitation totals, maximum intensities, total runoff, stormflow and stormflow coefficients for the Attert basin, Oak creek and Jalovecký creek.

\begin{tabular}{lcccccc}
\hline Catchment & Date event & $\begin{array}{c}\text { Total precip. } \\
(\mathrm{mm})\end{array}$ & $\begin{array}{c}\text { Max. precip. } \\
\left(\mathrm{mm} \cdot \mathrm{h}^{-1}\right)\end{array}$ & $\begin{array}{c}\text { Total runoff } \\
\text { volume } \\
(\mathrm{mm})\end{array}$ & $\begin{array}{c}\text { Stormflow } \\
\text { volume } \\
(\mathrm{mm})\end{array}$ & $\begin{array}{c}\text { Stormflow } \\
\text { coeff. } \\
(\%)\end{array}$ \\
\hline Attert basin & $03-05.12 .2011$ & 11.3 & 0.9 & 1.76 & 1.01 & 9.0 \\
Jalovecký creek & $13-14.09 .2012$ & 15.6 & 2.4 & 0.73 & 0.05 & 0.3 \\
Oak creek & $12-13.03 .2012$ & 40.1 & 6.6 & 9.9 & 6.92 & 17.3 \\
\hline
\end{tabular}


Summer 2012 was extremly dry in this catchment. No runoff event occurred since mid-June, which is very unusual. Therefore, the single rainfall event on $13^{\text {th }}$ September (Fig. 4) caused just a small runoff response. For the Attert River, the response was significantly higher with a stormflow coefficient of $9 \%$. Temporal distribution of rainfall in the Attert basin (Fig. 3) was different from that in the Jalovecký creek catchment. Several rainfall events which had occurred prior to the studied event had significantly increased catchment wetness. Thus, the runoff response to rainfall on $4^{\text {th }}$ December 2011 was more pronounced. The large total rainfall and the high maximum precipitation intensity monitored in the Oak creek (Fig. 5) generated a stormflow coefficient of approximately $17 \%$. Unlike in the other two catchments, a second flood hydrograph was triggered in the Oak creek catchment, although incident precipitation was relatively small during the second event. It could thus be assumed that the second event was dominated by delayed subsurface flow.

\section{Diatom assemblages}

Diatom assemblages and composition were very distinct between the three catchments in terms of species composition and functional species structure (Fig. 2). In the Attert basin in Luxembourg we found a higher species richness - i.e. species per sample $-(\mathrm{S}$ [number of species] $=149 ; \mathrm{n}$ [number of samples] $=$ 16), compared to the Oak creek in Oregon $(S=94 ; n=27)$ and the Jalovecký creek in Slovakia $(\mathrm{S}=49 ; \mathrm{n}=8)$. Most species were classified as 'mainly occurring in water bodies', but also 'regularly on wet and moist places' (Category 3 of Van Dam et al., 1994; Fig. 2). The Attert River and the Oak creek exhibited the highest number of aerial species (Categories $4 \& 5$ of Van Dam et al., 1994), with 21 and 20 species respectively. In the Jalovecký creek we only found 7 aerial species.

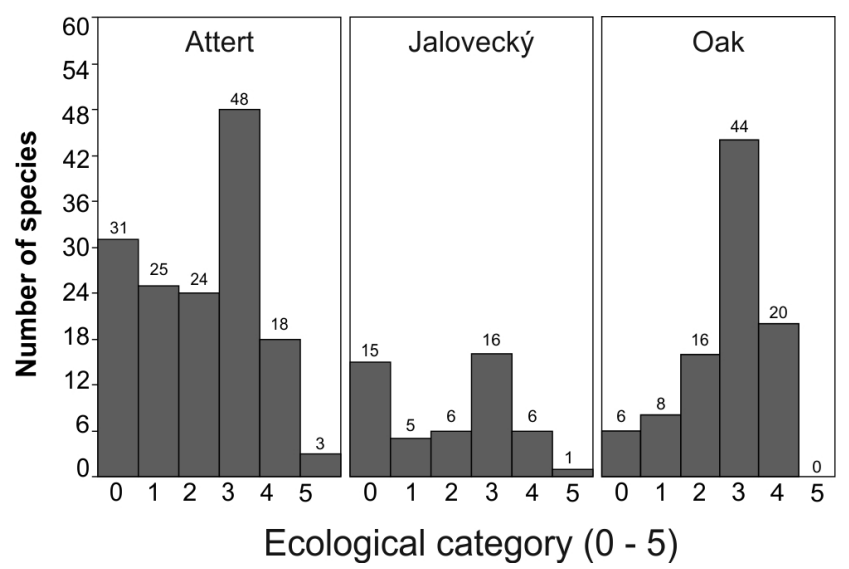

Fig. 2. Species distribution histogram according to the categories of Van Dam et al. (1994) in the Attert basin, Oak and Jalovecký creeks. Ecological categories for moisture conditions: $0=$ unknown; $1=$ never, or only very rarely, occurring outside water bodies; 2 mainly occurring in water bodies, sometimes on wet places; 3 = mainly occurring in water bodies, also rather regularly on wet and moist places; 4 = mainly occurring on wet and moist or temporarily dry places; $5=$ nearly exclusively occurring outside water bodies.

This can be explained by the fact that runoff response was very small in the Jalovecký creek. Isotopic data confirmed that runoff was dominated by the water which was stored in the catchment before the rainfall (isotopic data not shown here). Thus, the diatom data in the Jalovecký creek catchment represent low flow conditions, i.e. between the runoff events rather than a runoff event situation.

The maximum relative abundance of an individual species was lowest in the Attert River and in the Jalovecký creek, in comparison to the Oak creek. In the Attert River Hantzschia amhyoxis (Ehr.) Grunow (2.10\%) and Navicula tenelloides Hust. (1.57\%) were the most frequent aerial diatom species, while in the Jalovecký creek Nupela lapidosa (Krasske) LangeBert. (1.68\%) was most represented (Table 2). In relative numbers, the Oak creek had more aerial species than the other two catchments, with Nitzschia hantzschiana Lange-Bert. (12.44\%), Mayamaea atomus (Kütz.) Lange-Bertalot (5.94\%), Caloneis tenuis (W. Greg.) Krammer (3.17\%), Adlafia minuscula (Grunow) Lange-Bert. (2.00\%), Hantzschia abundans Lange-Bert. (1.49\%), Hantzschia amphioxys (Ehr.) Grunow (1.49\%), Hantzschia vivax (W. Smith) Grunow (1.21\%), Navicula subseminulum Hust. (1.07\%), and Pinnularia palatina Lange-Bert. \& W. Krüger $(1.02 \%)$ as the main aerial species. Only Hantzschia amphyoxis was common to the three catchments. A larger number of species could not be classified in the categories 1 to 5 as their ecology still remains unknown (in that case a default value of zero was attributed). The highest number of 'unknown' ecology (category 0) species was determined for the Attert River, where 31 species could not be classified in any of the categories (Fig. 2).

\section{Diatom drift}

The diatom drift observed in the Attert River (Fig. 3) was largely dominated by category 3 species (aquatic to subaerial). The contribution from this category decreased from $85 \%$ at low flow conditions to approximately 55\% at peak flow. Category 2 species (occasional aerophytic) increased from 5 to $20 \%$ during the runoff event. Throughout the event, category 1 species (aquatic strict) did not exhibit any specific trend (varying between 5 and 20\%). Categories 4 (aerophytic strict) and 5 (terrestrial) increased from zero to 5 and $0.5 \%$ respectively during the flood event.

In the Jalovecký creek (Fig. 4), the category 3 species (aquatic to subaerial) have dominated the diatom drift throughout the runoff event (approximately 75\%). No clear trend could be observed for categories 1 (aquatic strict, ranging between 0 and 5\%) and 2 (occasional aerophytic, ranging between 7 and 20\%). Category 4 (aerophytic strict) gradually decreased from approximately $4 \%$ prior to the rainfall event to almost zero percent during the runoff event. Category 5 (terrestrial) did not exhibit any trend during the runoff event, with values remaining close to zero percent during most of the observation period.

In the Oak creek (Fig. 5), contributions to diatom drift were highest from category 3 (aquatic to subaerial), decreasing from $88 \%$ prior to the precipitation event to $70 \%$ during the flood peak. Category 1 (aquatic strict) exhibited a high variability, with contributions ranging from 0.5 to $7 \%$ throughout the event. Contributions from category 2 (occasional aerophytic) slightly decreased from approximately $10 \%$ prior to precipitation to almost zero during the flood event. In the Oak creek, contributions from category 4 (aerophytic strict) increased from 0.5 at low flow to $25 \%$ at peak flow. Simultaneously, contributions from category 5 (terrestrial) increased from zero to $2 \%$. 
Table 2. List of aerial species (categories 4 and 5 of Van Dam et al., 1994) from the three catchments in Luxembourg (Attert River), Oregon (Oak creek) and Slovakia (Jalovecký creek). Maximal relative abundance (\%) values are shown and species with $>1 \%$ are marked in bold.

\begin{tabular}{|c|c|c|c|}
\hline Species & Attert basin & Jalovecký creek & Oak creek \\
\hline Achnanthes coarctata (Bréb. ex W. Smith) Grunow & 0.52 & & \\
\hline Adlafia bryophila (J.B. Petersen) Gerd Moser et al. & 0.52 & & \\
\hline Adlafia minuscula (Grunow) Lange-Bert. & & & 2.00 \\
\hline Caloneis molaris (Grunow) Krammer & & & 0.66 \\
\hline Caloneis tenuis (W. Greg.) Krammer & & & 3.17 \\
\hline Chamaepinnularia obsoleta (Hust.) C.E. Wetzel \& Ector & & & 0.25 \\
\hline Diploneis aff. krammeri Lange-Bert. \& E. Reichardt & & & 0.48 \\
\hline Eolimna tantula (Hust.) Lange-Bert. & 0.52 & & 5.49 \\
\hline Eunotia minor (Kütz.) Grunow & 0.52 & & 2.79 \\
\hline Eunotia paludosa Grunow & & & 0.66 \\
\hline Eunotia trinacria Krasske & 0.52 & & \\
\hline Fallacia insociabilis (Krasske) D.G. Mann & 0.51 & & \\
\hline Geissleria acceptata (Hust.) Lange-Bert. \& Metzeltin & 0.52 & 0.98 & \\
\hline Gomphonema aff. angustatum (Kütz.) Rabenh. & & & 5.17 \\
\hline Hantzschia abundans Lange-Bert. & 0.52 & & 1.49 \\
\hline Hantzschia amphioxys (Ehr.) Grunow & 2.10 & 0.48 & 1.49 \\
\hline Hantzschia vivax (W. Smith) Grunow & & & 1.21 \\
\hline Humidophila perpusilla (Grunow) Lowe et al. & & 0.65 & \\
\hline Luticola mutica (Kütz.) D.G. Mann & 0.52 & & \\
\hline Luticola nivalis (Ehr.) D.G. Mann & 0.52 & & \\
\hline Luticola ventricosa (Kütz.) D.G. Mann & 0.52 & & \\
\hline Mayamaea atomus (Kütz.) Lange-Bertalot & 0.51 & & 5.94 \\
\hline Microcostatus krasskei (Hust.) J.R. Johansen \& J.C. Sray & & 0.60 & \\
\hline Navicula cincta (Ehr.) Ralfs & 0.51 & & \\
\hline Navicula subseminulum Hust. & 0.26 & & 1.07 \\
\hline Navicula tenelloides Hust. & 1.57 & & 0.48 \\
\hline Nitzschia hantzschiana Lange-Bert. & & & 12.44 \\
\hline Nitzschia harderi Hust. & 0.51 & & \\
\hline Nitzschia solgensis Cleve-Euler & 0.50 & & \\
\hline Nitzschia terrestris (J.B. Petersen) Hust. & & & 0.49 \\
\hline Nupela lapidosa (Krasske) Lange-Bert. & & 1.68 & \\
\hline Pinnularia borealis Ehr. & & 0.65 & \\
\hline Pinnularia divergentissima (Grunow) P.T. Cleve & & & 0.50 \\
\hline Pinnularia palatina Lange-Bert. \& W. Krüger & & & 1.02 \\
\hline Placoneis hambergii (Hust.) Bruder \& Medlin & & & 0.66 \\
\hline Psammothidium bioretii (H. Germ.) Bukht. \& Round & 0.52 & & \\
\hline Psammothidium cf. marginulatum (Grunow) Bukht. \& Round & & 0.96 & \\
\hline Stauroneis thermicola (J.B. Petersen) J.W.G. Lund & 0.26 & & \\
\hline Tryblionella debilis Arn. ex O'Meara & 0.52 & & \\
\hline Maximum of aerial species per sample $=$ & $2.1 \%$ & $1.68 \%$ & $12.44 \%$ \\
\hline Number of aerial species $=$ & 21 & 7 & 20 \\
\hline
\end{tabular}





Fig. 3. Precipitation, discharge and percentages of diatom categories in streamwater (Attert River basin). 

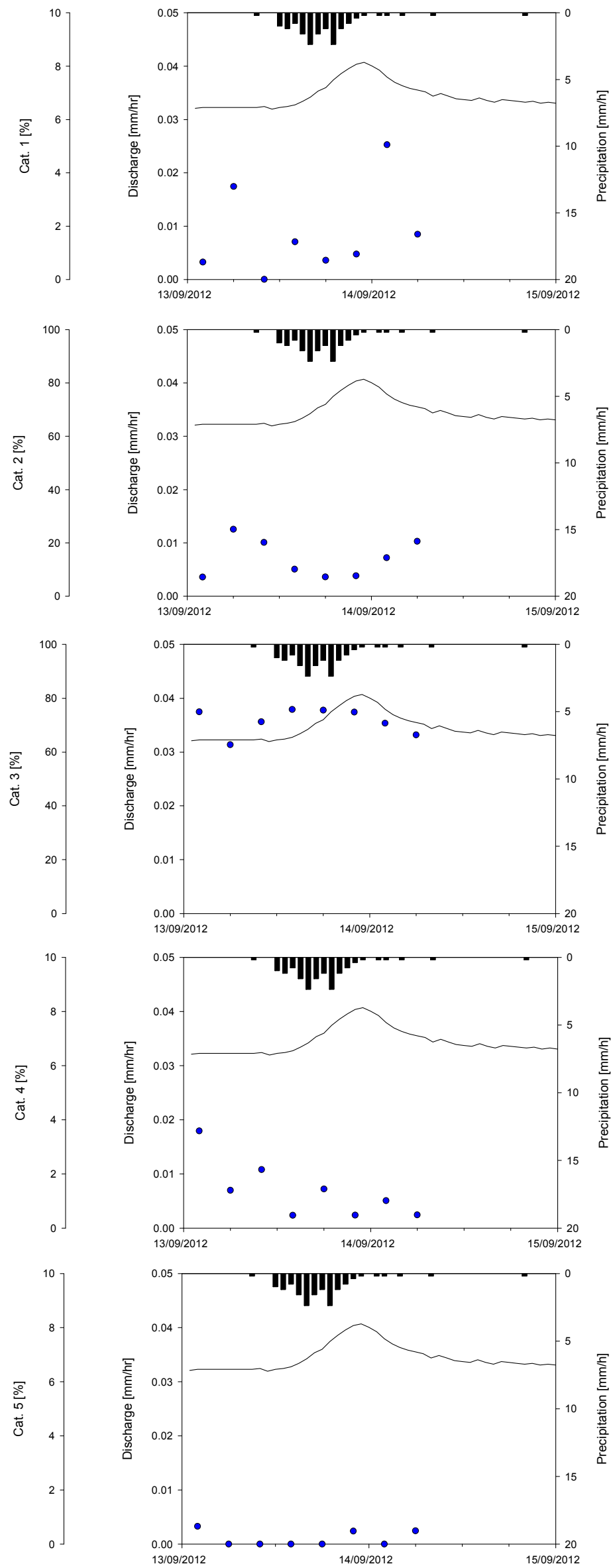

Fig. 4. Precipitation, discharge and percentages of diatom categories in streamwater (Jalovecký creek). 

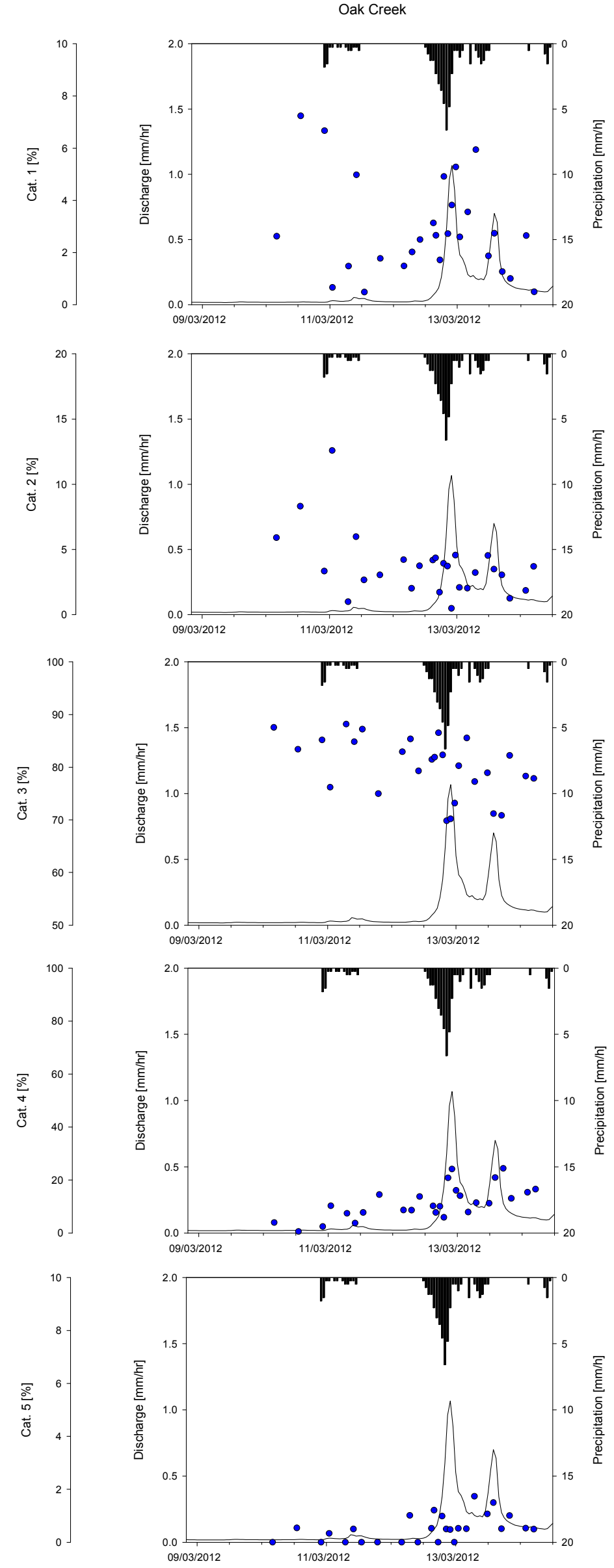

Fig. 5. Precipitation, discharge and percentages of diatom categories in streamwater (Oak creek). 


\section{DISCUSSION}

Diatom assemblages across sites: what did we find?

Our investigations showed very different diatom assemblages in the three studied catchments. We found the highest species richness in the Attert River basin (149 sp.), followed by the Oak creek (94 sp.) and the Jalovecký creek (49 sp.). While the number of collected samples was also smallest in the Jalovecký creek (the sampling protocols in the three catchments eventually being largely influenced by the size and shape of the observed hydrographs), we may nonetheless consider that this finding is likely to reflect the physiographic characteristics of the three studied catchments. The Oak creek and the Jalovecký creek catchments were much smaller than the Attert basin that covers a wide range of geological and land use settings. The size and physiographic diversity of the Attert basin appears to offer a larger variety of diatom habitats. The Oak creek and Jalovecký creek catchments exhibited less heterogeneous physiographical characteristics and consequently a smaller range of potential diatom habitats.

We found aerial diatom species in streamwater in all three catchments during the sampled rainfall-runoff events. While we identified 21 and 20 aerial species in the Attert River and Oak creek respectively, we only found 7 aerial species in the Jalovecký creek. The Oak creek exhibited the highest relative aerial species richness, with $21 \%$ of the total species population of the catchment. The presence of a very large riparian zone in the Oak creek, offering favourable conditions and habitats to aerial species, might explain this large difference in aerial species richness.

While a major finding of our study is that aerial diatoms are present in all three catchments and flushed to the streams during rainfall-runoff events, only one aerial species (Hantzschia amphioxys) was actually common to the three investigated catchments during the sampled events. To date, we have a very limited understanding on how aerial diatoms map across landscapes (Sherwood et al., 2014; Van Eaton et al., 2013), geological settings, or topographic and climatic gradients. The vast majority of investigations on the variability of diatom assemblages across regions have been limited to freshwater diatoms (e.g. Antoniades et al., 2014; Bottin et al., 2014; Hlúbiková et al., 2014). There have been virtually no investigations on aerial diatom communities along soil and/or altitude gradients. The vast majority of investigations on the relationships between (moss-inhabiting) diatoms and environmental conditions (moisture) has been focusing on the Antarctic region (e.g. Beyens, 1989; Gremmen et al., 2007; Kopalová et al., 2014; Van de Vijver and Beyens, 1998; Van de Vijver et al., 2008) with a few examples from the northern hemisphere in Europe (e.g. Nováková and Poulíčková, 2004; Veselá and Johansen, 2009) and North America (e.g. Johansen et al., 1981, 2004; Lowe and Collins, 1973; Lowe et al., 2007).

The presence of aerial diatoms in our three study catchments is an important prerequisite for their general use as a tracer of hydrological processes. Moreover, the obvious relationship between aerial diatom assemblages and prevailing physiographic characteristics opens new possibilities for the use of diatoms as a tracer of water source across multiple scales and physiographic contexts. Prior to that, though, systematic investigations are still required for characterizing aerial diatom assemblages across landscapes, as well as determination of diatom reservoir sizes and depletion during rainfall flushing (Coles et al., 2015).

\section{Drift diatom mobilization during events}

Precipitation events monitored in the Attert basin and Oak creek catchment triggered significant increases in discharge. Due to a 3 months dry spell, the precipitation event recorded in the Jalovecký creek catchment only generated a very small response. These differences are likely related to the fact that sampling campaigns in the Attert River basin and the Oak creek catchment took place during the winter period, when the catchments had already been through a significant wetting-up phase. In the Jalovecký creek, sampling was conducted in late summer, shortly after unusually dry conditions.

The diatom drift analysis showed differences between catchments in the relative contributions from the five diatom categories. Contributions from category 1 (aquatic strict) were minimal and not related to changes in discharge in all three catchments. While contributions through category 2 (occasional aerophytic) roughly ranged between 10 and $20 \%$ in the Jalovecký creek (with an apparent decrease during the rainfall event), they were less significant and showed opposite trends in the Attert River (increasing) and the Oak creek (a slight decrease). Contributions from category 3 (aquatic to subaerial) largely dominated in all three catchments. While in the Jalovecký creek they remained rather stable throughout the rainfall-runoff event, contributions decreased with rising discharge in the Oak creek and the Attert River. In the Oak creek, this decrease was largely compensated by a strong increase in contributions from category 4 (aerophytic strict). In the Attert River, this compensation effect was essentially driven by rising contributions from category 2 , and to a much lesser extent by those from category 4 . Relative contributions through category 5 (terrestrial) were close to zero in the Jalovecký creek. While being most of the time close to zero in the Jalovecký creek and the Attert River, they temporarily reached values close to $2 \%$ in the Oak creek during the rainfall-runoff event.

The very small changes observed in contributions from categories 4 and 5 (aerial diatoms) in the mountainous Jalovecký creek tend to suggest a limited contribution of rapid flowpaths to discharge generation. This is consistent with the low stormflow coefficient and with our knowledge of the catchment's behaviour, i.e. rare overland flow and high infiltration capacities of the soils (Holko and Kostka, 2006) and with isotopic data collected during the event (data not shown here). In the Attert River we observed a noticeable increase in combined contributions through categories 4 and 5, suggesting a more significant role of near-stream aerial diatom reservoirs (and thus eventually temporarily connected riparian zones). This is also implied by the substantial stormflow coefficient of $9 \%$. This effect was even more exacerbated in the Oak creek, where we observed the strongest increase in combined contributions by categories 4 and 5 , alongside a substantial stormflow coefficient of $17 \%$. From these findings we can infer the existence of aerial diatom reservoirs and their temporary connectedness - through rapid surface or subsurface flowpathways - to the stream network in all three catchments. However, the differences in the flushing responses might be related to differing diatom reservoir sizes and/or contrasted rapid water flow pathways, as well as the noticeable differences in precipitation intensities observed in the three catchments. 


\section{CONCLUSION}

Our investigations in three contrasted catchments were a follow-up to the work of Pfister et al. (2009). We have been able to confirm that aerial diatoms can be found in all three catchments and that they are flushed to the streams during rainfall-runoff events. The existence of aerial diatom reservoirs and their connectedness to the stream are fundamental prerequisites for their application as hydrological tracers.

We compared the abundances of diatom communities in three catchments with contrasting physiographic characteristics. Categories 4 and 5 (aerial diatoms) were mobilized in all three investigated catchments during a rainfall-runoff event. While these results document the existence of diatom reservoirs in each study catchment, their respective size and connectedness to the stream network exhibited significant differences. Strictly aerophytic communities showed a clear increase during the events in wetter conditions in the Attert and Oak creek catchments. They did not vary during the small event that occurred after a long dry period in the Jalovecký creek catchment. Further investigations are needed for assessing the spatial and temporal variability of aerial diatom reservoirs in individual catchments - as a function of prevailing environmental conditions.

Beyond tracking their existence in very contrasted environments, further research on aerial diatoms is needed. Diatom reservoir size and the probability of diatom supply being exhausted during prolonged rainfall events is of crucial interest in the context of hydrological studies. Furthermore, we need to explore the (species-specific) diatom concentration-discharge relationships during flood hydrographs. If clockwise or counterclockwise hysteretic, these relationships could indicate hydrological processes such as 'wash off' or shallow subsurface transport routes. With aerial diatoms being occasionally observed during low flow conditions, we need to investigate how conservatively diatoms are transported downstream, or whether they are deposited temporarily.

Acknowledgements. We thank Jay Frentress for logistical and technical support during the field campaign in Oregon. We are grateful for the support of Lionel Lhoste in preparing the diatom slides. This research was carried out in the framework of the ECSTREAM research project, funded by the National Research Fund of Luxembourg (Grant C12/SR/4018854).

\section{REFERENCES}

Antoniades, D., Douglas, M.S.V., Michelutti, N., Smol, J.P., 2014. Determining diatom ecotones and their relationship to terrestrial ecoregion designations in the central Canadian Arctic Islands. J. Phycol., 50, 610-623.

Beyens, L., 1989. Moss dwelling diatom assemblages from Edgeøya (Svalbard). Polar Biol., 9, 423-430.

Bottin, M., Soininen, J., Ferrol, M., Tison-Rosebery, J., 2014. Do spatial patterns of benthic diatom assemblages vary across regions and years? Freshw. Sci., 33, 402-416.

Brendemühl, I., 1949. Über die Verbreitung der Erddiatomeen. [On the distribution of terrestrial diatoms]. Arch. Mikrobiol., 14, 407-449. (In German.)

Burns, D.A., 2002. Stormflow-hydrograph separation based on isotopes: the thrill is gone-what's next? Hydrol. Process., 16, 1515-1517.

Coles, A.E., Wetzel, C.E., Martínez-Carreras, N., Ector, E., McDonnell, J.J., Frentress, J.J., Klaus, J., Hoffmann, L., Pfister, L., 2015. Diatoms as a tracer of hydrological connectivity: are they supply limited? Ecohydrol. (submitted).
Ettl, H., Gärtner, G., 2014. Syllabus der Boden-, Luft- und Flechtenalgen.[Syllabus of the soil, air and lichen algae]. 2nd Ed. Springer, Berlin Heidelberg, 773 p. (In German.)

European Committee for Standardization, 2003. Water quality guidance standard for the routine sampling and pretreatment of benthic diatoms from rivers [EN 13946:2003]. European Committee for Standardization, Brussels.

European Committee for Standardization, 2014. Water quality guidance standard for the identification, enumeration and interpretation of benthic diatom samples from running waters [EN 14407:2014]. European Committee for Standardization, Brussels.

Falasco, E., Bona, F., Isaia, M., Piano, E., Wetzel, C.E., Hoffmann, L., Ector, L., 2015. Nupela troglophila sp. nov., an aerophilous diatom (Bacillariophyta) from the Bossea cave (NW Italy), with notes on its ecology. Fottea, 15 (in press).

Furey, P.C., Lowe, R.L., Johansen, J.R., 2011. Eunotia Ehrenberg (Bacillariophyta) of the Great Smoky Mountains National Park, USA. In: Lange-Bertalot, H., Kociolek, J.P. (Eds.): Bibliotheca Diatomologica 56. Gebr. Borntraeger Verlagsbuchhandlung, Stuttgart, $133 \mathrm{p}$.

Furey, P.C., Mayama, S., Lowe, R.L., Catenazzi, A., 2012. Frankophila wayqechae sp. nov., a new aerophilic diatom species from the Peruvian Andes, South America. Diatom Res., 27, 165-175.

Gremmen, N.J.M., Van de Vijver, B., Frenot, Y., Lebouvier, M., 2007. Distribution of moss-inhabiting diatoms along an altitudinal gradient at sub-Antarctic Îles Kerguelen. Antarct. Sci., 19, 17-24.

Hannah, D.M., Sadler, J.P., Wood, J.P., 2007. Hydroecology and ecohydrology: a potential route forward? Hydrol. Process., 21, 3385-3390.

Hlúbiková, D., Novais, M.H., Dohet, A., Hoffmann, L., Ector, L., 2014. Effect of riparian vegetation on diatom assemblages in headwater streams under different land uses. Sci. Total Environ., 475, 234-247.

Hofmann, G., Werum, M., Lange-Bertalot, H., 2011. Diatomeen im Süßwasser-Benthos von Mitteleuropa. [Freshwater benthic diatoms from Central Europe]. Bestimmungsflora Kieselalgen für die ökologische Praxis. Über $700 \mathrm{der}$ häufigsten Arten und ihre Ökologie. A.R.G. Gantner Verlag K.G., Rugell, 908 p. (In German.)

Holko, L., Kostka, Z., 2006. Hydrological research in a highmountain catchment of the Jalovecký creek. J. Hydrol. Hydromech., 54, 192-206.

Hooper, R.P., Christophersen, N., Peters, N.E., 1990. Modelling streamwater chemistry as a mixture of soilwater endmembers - an application to the Panola Mountain catchment, Georgia, U.S.A. J. Hydrol., 116, 321-343.

Hustedt, F., 1942. Aërophile Diatomeen in der nordwestdeutschen Flora. [Aerial diatoms of north-western Germany]. Ber. Deutsch. Bot. Ges., 60, 55-73. (In German.)

Johansen, J.R., 2010. Diatoms of aerial habitats. In: Smol, J.P., Stoermer, E.F. (Eds.): The Diatoms: Applications for the Environmental and Earth Sciences. 2nd Ed. Cambridge University Press, Cambridge, 465-472.

Johansen, J.R., Rushforth, S.R., Brotherson, J.D., 1981. Subaerial algae of Navajo National Monument, Arizona. Great Basin Nat., 41, 433-439.

Johansen, J.R., Lowe, R., Gomez, S.R., Kociolek, J.P., Makosky, S.A., 2004. New algal species records for the Great Smoky Mountains National Park, U.S.A, with an annotated checklist of all reported algal species for the park. Algol. Stud., 111, 17-44. 
Kopalová, K., Ochyra, R., Nedbalová, L., Van de Vijver, B., 2014. Moss-inhabiting diatoms from two contrasting Maritime Antarctic islands. Plant Ecol. Evol., 147, 67-84.

Kundzewicz, Z.W., 2012. Ecohydrology - seeking consensus on interpretation of the notion. Hydrolog. Sci. J., 47, 799804.

Lecointe, C., Coste, M., Prygiel, J., 1993. "Omnidia": software for taxonomy, calculation of diatom indices and inventories management. Hydrobiologia, 269/270, 509-513.

Lowe, R.L., Collins, G.B., 1973. An aerophilous diatom community from Hocking County, Ohio. Trans. Am. Microsc. Soc., 92, 492-496.

Lowe, R.L., Furey, P.C, Ress, J.A., Johansen, J.R., 2007. Diatom biodiversity and distribution on wetwalls in Great Smoky Mountains National Park. Southeast. Nat., Special Issue, 1, 135-152.

Lund, J.W.G., 1945. Observations on soil algae. I. The ecology, size and taxonomy of British soil diatoms. New Phytol., 44, 196-219.

Martinec, J., 1975. Subsurface flow from snowmelt traced by tritium. Water Resour. Res., 11, 496-498.

Martínez-Carreras, N., Wetzel, C.E., Frentress, J., Ector, L., McDonnell, J.J., Hoffmann, L., Pfister, L., 2015. Hydrological connectivity as indicated by transport of diatoms through the riparian-stream system. Hydrol. Earth Syst. Sci. Discuss., 12, 2391-2434. doi: 10.5194/hessd-12-2391-2015.

McGuire, K.J., McDonnell, J.J., 2006. A review and evaluation of catchment transit time modeling. J. Hydrol., 330, 543563.

Nováková, J., Pouličcková, A., 2004. Moss diatom (Bacillariophyceae) flora of the Nature Reserve Adršpašsko-Teplické Rocks (Czech Republic). Czech Phycol., 4, 75-86.

Petersen, J.B., 1915. Studier over danske aërofile alger. [Studies of aerial diatoms in Denmark]. D. Kgl. Danske Vidensk. Selsk. Skrifter, 7 Raekke, Naturvidensk. og Mathem. Afd., 12, 269-380. (In Danish.)

Petersen, J.B., 1928. The aerial algae of Iceland. In: Rosenvinge, L.K., Warming, E. (Eds.): The Botany of Iceland, vol. 2, part 2, no. 8. J. Frimodt, Copenhagen, and John Wheldon and Co., London, pp. 325-447.

Petersen, J.B., 1935. Studies on the biology and taxonomy of soil algae. Dansk Bot. Ark., 8, 9, 1-183.

Pfister, L., McDonnell, J.J., Wrede, S., Hlúbiková, D., Matgen, P., Fenicia, F., Ector, L., Hoffmann, L., 2009. The rivers are alive: on the potential for diatoms as a tracer of water source and hydrological connectivity. Hydrol. Process., 23, 28412845.

Pfister, L., Iffly, J.F., El Idrissi, A., Hoffmann, L., 2000. Définition de zones hydrologiquement homogènes au Grand-Duché de Luxembourg sur base de critères physiogéographiques en vue d'opérations de régionalisation. [Definition of hydrologically homogeneous regions in the Grand-duchy of Luxembourg based on physiogeographic criteria]. Arch. Inst. g.-d. Luxemb., Sect. Sci. nat. phys. math., 43, 239-253. (In French.)

Round, F.E., Crawford, R.M., Mann, D.G., 1990. The diatoms. Biology and morphology of the genera. Cambridge University Press, Cambridge, $747 \mathrm{p}$.

Salvia-Castellví, M., Iffly, J.F., Vander Borght, P., Hoffmann, L., 2005. Dissolved and particulate nutrient export from rural catchments: A case study from Luxembourg. Sci. Total Environ., 344, 51-65.
Sherwood, A.R., Conklin, K.Y., Liddy, Z.J., 2014. What's in the air? Preliminary analyses of Hawaiian airborne algae and land plant spores reveal a diverse and abundant flora. Phycologia, 53, 579-582.

Simonsen, R., 1987. Atlas and Catalogue of the Diatom Types of Friedrich Hustedt. J. Cramer, Berlin - Stuttgart, 525 p., 772 pls.

Sklash, M.G., Farvolden, R.N., 1979. The role of groundwater in storm runoff. J. Hydrol., 43, 45-65.

Smol, J.P., Stoermer, E.F. (Eds.), 2010. The Diatoms: Applications for the Environmental and Earth Sciences. 2nd Ed. Cambridge University Press, Cambridge, 667 p.

Tauro, F., Martínez-Carreras, N., Barnich, F., Juilleret, J., Wetzel, C.E.W., Ector, L., Hissler, C., Pfister, L., 2015. Diatom percolation through soils: a proof of concept laboratory experiment. Ecohydrol. (submitted).

Tetzlaff, D., Soulsby, C., Bacon, P.J., Youngson, A.F., Gibbins, C., Malcolm, I.A., 2007. Connectivity between landscapes and riverscapes - a unifying theme in integrating hydrology and ecology in catchment science. Hydrol. Process. 21, $1385-1389$.

Van Dam, H., Mertens, A., Sinkeldam, J., 1994. A coded checklist and ecological indicator values of freshwater diatoms from The Netherlands. Neth. J. Aquat. Ecol., 28, 117-133.

Van de Vijver, B., Beyens, L., 1998. A preliminary study on the soil diatom assemblages from Ile de la Possession (Crozet, Subantarctica). Eur. J. Soil Biol., 34, 133-141.

Van de Vijver, B., Gremmen, N., Smith, V., 2008. Diatom communities from the sub-Antarctic Prince Edward Islands: diversity and distribution patterns. Polar Biol., 31, 795-808.

Van Eaton, A.R., Harper, M.A., Wilson, C.J.N., 2013. Highflying diatoms: Widespread dispersal of microorganisms in an explosive volcanic eruption. Geology, 41, 1187-1190.

Veselá, J., Johansen, J.R., 2009. The diatom flora of ephemeral headwater streams in the Elbsandsteingebirge region of the Czech Republic. Diatom Res., 24, 443-477.

Werum, M., Lange-Bertalot, H., 2004. Diatomeen in Quellen unter hydrogeologischen und anthropogenen Einflüssen in Mitteleuropa und anderen Regionen. [Diatoms in springs from Central Europe and elsewhere under the influence of hydrologeology and anthropogenic impacts]. Iconogr. Diatomol., 13, 3-417. (In German.)

Wetzel, C.E., Van de Vijver, B., Kopalová, K., Hoffmann, L., Pfister, L., Ector, L., 2014. Type analysis of the South American diatom Achnanthes haynaldii (Bacillariophyta) and description of Planothidium amphibium sp. nov., from aerial and aquatic environments in Oregon (USA). Plant Ecol. Evol., 147, 439-454.

Wu, N., Faber, C., Ulrich, U., Schmalz, B., Fohrer, N., 2014. Diatoms as an indicator for tile drainage flow in a German lowland catchment. Geophysical Research Abstracts, 16, EGU2014-4955-2.

Zimmermann, J., Abarca, N., Enk, N., Skibbe, O., Kusber, W.H., Jahn, R., 2014. Taxonomic reference libraries for environmental barcoding: a best practice example from diatom research. PLoS ONE, 9, 9, e108793.

Received 12 January 2015 Accepted 5 May 2015

Note: Colour version of Figures can be found in the web version of this article. 